\title{
The Influencing Factors of Innovation and Entrepreneurship of College Students
}

\author{
Zhang Heng \\ School of Innovation and Entrepreneurship, Xi'an Fanyi University, Xi'an, Shaanxi, China, 710105
}

Keywords: college students; innovation and entrepreneurship; influencing factors

\begin{abstract}
With the slogan of "national entrepreneurship and innovation", the innovation and entrepreneurship of college students has entered a new period of explosion under the strong support of government policies. This paper analyzes the subjective factors and social objective factors of college students' innovation and entrepreneurship, analyzes the important influencing factors such as entrepreneurial experience, characteristics of entrepreneurship, policy guarantee and enterprise support, and tries to provide a reference for finding relevant difficulties.
\end{abstract}

\section{Introduction}

College students' innovation and entrepreneurship has become an important part of the current national economy, and the innovation and entrepreneurship of college students has become a unique force in society. Although the innovation and entrepreneurship of college students has become a trend, the success of entrepreneurship and entrepreneurship is determined by many factors. This paper mainly analyzes the subjective factors of college students and the objective factors of society. Under the slogan of "national entrepreneurship and innovation", there are many important factors of the innovation and entrepreneurship experience, such as entrepreneurial characteristics, policy guarantee, enterprise support and other important factors. And through the research of this paper, it is found that there are two obvious characteristics of innovation and entrepreneurship of college students: First, the entrepreneurial activity is carried out on the basis of scientific and technological innovation, which requires a great deal of knowledge and experience accumulation. Second, it is mainly through the establishment of small and micro enterprises to transform their innovation and entrepreneurship achievements.

\section{Subjective Factors of Innovation and Entrepreneurship of College Students}

\subsection{Influencing factors of entrepreneurial motivation}

The data on innovation and entrepreneurship of Chinese college students shows that the proportion of students in business administration is significantly higher than that of humanities and science and technology students, which is directly related to the students' academic characteristics and professional advantages. Because of the more economic and managerial knowledge, and the acceptance of the theory and incentive of independent entrepreneurship, the business administration students are more professional than other majors. This kind of incentive will have a decisive effect on the formation of its entrepreneurial consciousness, and its participation in the social practice will increase its own entrepreneurial tendency. However, the low level of entrepreneurial initiative will directly hinder the innovation and entrepreneurship of college students.

\subsection{Influencing factors of interpersonal communication skills}

The essential factor for an entrepreneur is good interpersonal communication skills. And this ability not only has a great influence on the development of the future, but also plays a decisive role in the success of the future career. Interpersonal communication skills are an essential quality for independent entrepreneurs, and this quality will affect the success rate of entrepreneurs promoting their products and financing. When college students start their own business, their interpersonal 
relationship and human resources are less, and their social resources are weaker. So, their interpersonal communication skills will become more important.

\subsection{Influencing factors of entrepreneurial traits}

College students will encounter various problems and setbacks in the process of innovation and entrepreneurship. In the face of these problems and setbacks, we must have the quality to solve problems and solve problems. When facing a heavy blow, we must have the spirit of perseverance and strong entrepreneurial intention. This entrepreneurial trait will have a direct impact on the success rate of the final startup. Only entrepreneurs with great ambition and perseverance can finally succeed.

\section{Objective Factors of Innovation and Entrepreneurship of College Students}

\subsection{Influencing factors of policy guarantee}

The process of innovation and entrepreneurship is a dynamic, complex and diverse process. In this process, it is essential to find the key points to support entrepreneurship and encourage entrepreneurship. Only by finding this key point can we effectively support and encourage college students to start their own business and succeed. In the study on global entrepreneurship competitiveness, Solomon \& Theron studied the population base and growth rate, GDP and entrepreneurial activity of 9 developed countries and 6 emerging economies. Finally, it is believed that the establishment and implementation of college students' entrepreneurship encouragement policy is of great help to domestic entrepreneurship. There are three aspects to support innovation and entrepreneurship as following. First, policy guarantee should stimulate their entrepreneurial passion. Secondly, practical knowledge and skills training should be held in entrepreneurship training. Third, the government should provide funds, office, tax incentives and other incentives to encourage entrepreneurship.

\subsection{Influencing factors of enterprise support}

If a recent graduate does not have an internship in the enterprise, he will not understand the basic operation of the company and the way of handling problems. So, the solution may not be accurate enough for recent graduates. We can cultivate students' entrepreneurial knowledge and skills through enterprise as the innovation platform. Under the condition of students' experience and social practice ability, the success rate of students will be greatly increased through the support of enterprises. We should get college students to get some experience after they get into practice and then start their own business. And then use enterprise micro platform to improve their capital and network resources reserve and accumulation.

\section{Strategies for Improving Entrepreneurial Ability of College Students}

\subsection{Cultivating the basic entrepreneurial characteristics of college students}

Students' entrepreneurial awareness and entrepreneurial traits have a great boost. Only through publicity can we develop an atmosphere suitable for cultivating college students' entrepreneurship. Colleges and universities should enhance students' enthusiasm for participation through various entrepreneurship competitions, lectures or training. Colleges and universities enable college students to actively participate in the practice of entrepreneurship. College students actively participate in the entrepreneurial practice, in the process, to enhance their pioneering consciousness, risk assessment, business management skills such as basic entrepreneurial qualities. In addition, before starting a business, college students must have a solid professional knowledge and skills to understand the legal, financial, management and marketing knowledge needed by the company. College students enhance their own basic characteristics by improving their interpersonal communication and coordination ability. And thoruth the entrepreneurial training base formed by the state, universities and enterprises to enhances the basic competency of entrepreneurs. 


\subsection{Strengthen the basic knowledge and skills of college students}

The practical activities of college students before entering the society mainly include graduation practice and graduation field practice, etc. This kind of practical activity can consolidate college students' basic knowledge skills and professional theoretical knowledge to a large extent, and can be more clear about the ability and quality of the society for this major. College students should pay attention to social practice and accumulate human resources and expand social relations in the process of social practice. On the basis of in-depth social needs, college students choose the entrepreneurial projects with high implementation, and strengthen their basic knowledge and skills according to the entrepreneurial projects.

\subsection{Strengthen the support of venture funds}

It is necessary to constantly strengthen the support of venture funds to enhance the enthusiasm of college students to start their own business, and to provide financing channels for high profit and entrepreneurial projects. The initial start-up capital of a fresh graduate is usually a part of the cost of living expenses or family expenses. It can be said that its capital chain is very weak, it is difficult to bear the social impact in a short time. So, it is of great help to strengthen the support of enterprise venture fund and expand the loan financing channels of college students' entrepreneurship.

\subsection{Strengthen the implementation of entrepreneurship policy}

The Chinese government has a very strong support policy for college students' innovation and entrepreneurship. However, because some departments do not implement policy implementation, this situation will lead some college students not to get the practical help of preferential policies. So, local governments in China should strengthen their policies and policies towards the central government. The government should fully publicize the preferential policies and strengthen the cognition degree of college students on preferential policies. Only in this way, more college students will receive the benefit of government preferential policies when they start their own business.

\section{Conclusion}

The trend of China's "national entrepreneurship and innovation" has created a new situation for college students' innovation and entrepreneurship in China. This paper analyzes the influencing factors of college students' innovation and entrepreneurship. It lays a foundation for optimizing our education resource allocation and innovation.

\section{Acknowledgement}

Project of Science \& Technology Bureau, Chang'an District, Xi'an: Research on Construction of Chuang Yi Incubation Base of Xi'an FANYI University NO. CC1702

\section{References}

[1] H.H. Stevenson, M.J. Robert, H.Lgrousbeck . New Business Ventures and the Entrepreneur. Irwin: Homewood (2013), p. 12-14

[2] Shane, B, Venkataraman, S. The Promise of Entrepreneurship as a Field of Research. Academy of Management Review (2013), p. 22-25

[3] Krueger, N.F. The cognitive infrastructure of opportunity emergence. Entrepreneurship Theory and Practice (2013), p. 124-126

[4] ISBA Consortium. Making the journey from student to entrepreneur: A review of the existing research into graduate entrepreneurship. National Council for Graduate Entrepreneurship-NCGE, Birmingham (2014), p. 37-39 
[5] Audretsch, David, B.A. RoyThurik. What is new about the new economy, Sources of growth in the managed and entrepreneurial economies. Industrial and Corporate Change (2013), p. 65-67

[6] Audretsch, David B. A. Roy Thurik. Capitalism and Democracy in the 21 st Century: from the Managed to the Entrepreneurial Economy. Journal of Evolutionary Economics (2013), p. 62-65

[7] FranciscoLiIan, Francisco Javier Santos. Does social capital affectintentions. Int. Adv. Econ. Rev (2007), p. 38-39

[8] Stevenson, Lois, Lundstrom, Anders. Swedish Foundation for Small Business Research. Policy for the Future (2013), p. 68-80 